\title{
Seasonal variation and diversity of carabid beetles fauna (Coleoptera: Carabidae) in coastal areas of Sindh, Pakistan
}

\author{
Reshma Sahito*, Nasreen Memon and Aiman Amur
}

Department of Zoology, University of Sindh, Jamshoro-Pakistan

*Corresponding author's email: resham.sahito@gmail.com

\section{Citation}

Reshma Sahito, Nasreen Memon and Aiman Amur. Seasonal variation and diversity of carabid beetles fauna (Coleoptera: Carabidae) in coastal areas of Sindh, Pakistan. Pure and Applied Biology. Vol. 9, Issue 2, pp15561567. http://dx.doi.org/10.19045/bspab.2020.90163

Received: $13 / 12 / 2019 \quad$ Revised: $25 / 02 / 2020$

Accepted: 05/03/2020

Online First: 16/03/2020

\section{Abstract}

Seasonal variation in abundance and diversity of carabid fauna was studied in eight different localities of coastal areas of Sindh during august 2018-July 2019. Individuals were trapped using soil traps and light traps. A total 1303 ground beetles of 4 subfamilies 8 genera 12 species. The individuals of subfamily Harpalini were higher 508 followed by Carabinae 462 while least number of subfamily Brachinae 130 followed by Lebinae with 157 was recorded. Among these three most abundant species, Calosoma aurapunctuatum, Calosoma scyophantum and anthia Sexuamatta and least abundant Mecyclothorax cordicolis were recorded. The abundance of Carabidofauna differed with seasonal fluctuations. The highest population was recorded in summer season followed by spring, whereas least abundance was observed in winter. Monthly population dynamics showed that Carabid beetles were highest in number in the months of June, July followed by August and September while least population was recorded in February followed by January and December. The maximum average population size and Simpson reciprocal index was found at Sujawal (29.7\%) and Thatta (9.74) respectively, and lowest both average population size and Simpson reciprocal diversity index for Karachi locality (11.4\%) and (5.73). Pearson Correlation coefficient (r) analysis showed strong positive and significant relationship of carabid beetles abundance with humidity, temperature and rainfall, $(\mathrm{r}=0.65, \mathrm{p}=0.02),(\mathrm{r}=.810, \mathrm{p}=.0001)$ and $(\mathrm{r}=0.65, \mathrm{p}=0.02)$ respectively. Locality wise average population size, evenness and diversity indexes were calculated, and highest population was recorded in concern with high relative humidity and temperature in the locality.

Keywords: Carabidofauna; Climatic factors; Harpalinae; Sindh; Sujawal

\section{Introduction}

The Carabidae family is commonly known as "Ground Beetles," one of the ten largest beetle families in the order Coleoptera. This family was established by Latreille in 1802 at that time it was composed of 29 genera. Now adays, the family Carabidae contains an estimated 40,000 described species, 1860 genera and 100 tribes [1]. They are important and beneficial insects for ecosystem because 
they are used as ecological indicators and biological control agents for pests. It is doable using biological indicator evaluation, rather checking the influence of the entire biota human disturbances. More importantly, they are helpful to provide early warning of changes in species [2]. As an ecological indicator they reveal the stability of both natural ecosystem and polyphagous communities that directly affects plant distribution simultaneously reflects the abundance and diversity of other fauna that one may increase the plant species ultimately the phytophagous and predacious arthropod species higher distribution. When concerning the effect of biodiversity on a setup, the two main ideas are important the productivity and the stability [3].

In ecology, a new idea is that stability in the function of natural ecosystems and multitrophic community directly affects plant diversity. Plant species diversity may strongly impact on the abundance and distribution of other creatures, in order to increase the number of plant species, promote individual herbivorous and predatory arthropod species diversity in higher [4]. They are found in a global range of microhabitats including the under soil, under bark of trees, sea beaches, cracks under rocks, $\operatorname{logs}$ and stones at the margins of a high mountain. They are polyphagous, many carabids are predacious. Many of them are generalist predators and are divided based on food preferences as carnivores, herbivores, saprophagous and omnivores, but here are several groups that have become specialized (e.g., Peleciini and Promecognathini on millipedes, Cychrini and Licinini on snails). A few clades have larvae that are ectoparasites on other arthropods (e.g., Lebiini, Brachini, and Peleciini). Others are seedeaters (e.g., Harpalini). Each species of ground beetle has specific environmental requirements $[5,6]$. Knowledge of these requirements helps in recognizing species typical of a study site for those wandering through it. Ground beetles also are good indicators of habitat types and environmental quality in terms of the effects of pesticides [7, 8]. Seasonal variations in carabid beetles abundances and biogenic is observed in many tropical (sweltering) and temperate regions [9-11]. In general, abundances and biogenic are highest during humid and the wet season while lowest during the cold and dry season. Despite that, there is a great fluctuation in species composition throughout a year [12]. Different insect groups have their highest abundance in different times of the year [13, 14], species might have one or several peaks in abundance or have relatively stable abundance. Seasonal variability of ground beetles is speculated in variation of abundances, spawning time(s), dormancy period and larval development [15, 16]. However, many species reveal flexibility in their seasonal periodicity during disturbed habitats, species may have resilience lifecycles allowing them to breed at different times of the year [17]. Their habitats and micro distribution are modelled molded by abiotic and biotic factors such as light, temperature, humidity, food supply, predator distribution, and life cycle strategies [18], but abiotic factors explain the distribution of species better than biotic factors [19]. In Sindh very little is known for ground beetle fauna but no previous record is found about ground beetles diversity and seasonal cycles The main objectives of this investigation was to recognize peaks in seasonal variability, abundance of carabid beetles and diversity also revealed the variation in ground beetle abundance with respect to climatic factors (temperature, humidity and rainfall).

\section{Materials and methods}

This study was carried out from august 2018July 2019 in coastal areas of Sindh like Thatta, Makli, Keenjher, Sujawal, Ghorabri, Daro and Karachi, situated at south of Sindh. The district Thatta is located right bank of 
river Indus at latitude $24.7423^{\circ} \mathrm{N}$, longitude $67.92^{\circ} \mathrm{E}$ and $8 \mathrm{~m}$, while Sujawal on left bank at latitude $24.6042^{\circ} \mathrm{N}$ longitude of $68.0776^{\circ}$ $\mathrm{E}$ and $4 \mathrm{~m}$. Coastal areas of Sindh have a subtropical climate with moderate summer and cold winter round about the year. The soil of this region is silty with a little clay and characterized by different crops, vegetations and shrubs everywhere (Table 1).

Table 1. GPS Coordinates (Latitude, Longitude \& Altitude) of surveyed localities of Coastal areas of Sindh

\begin{tabular}{|c|c|c|c|}
\hline Locality & Latitude & Longitude & Altitude/Elevation (in meters)1 \\
\hline 1. Ghorabri & $24.24^{\circ} 0^{\circ} \mathrm{N}$ & $67.4960^{\circ} \mathrm{E}$ & 10 \\
\hline 2. Sujawal & $24.6042^{\circ} \mathrm{N}$ & $68.0776^{\circ} \mathrm{E}$ & 4 \\
\hline 3. Thatta & $24.7423^{\circ} \mathrm{N}$ & $67.92^{\circ} \mathrm{E}$ & 8 \\
\hline 4. Daro & $24.7931^{\circ} \mathrm{N}$ & $67.6260^{\circ} \mathrm{E}$ & 6 \\
\hline 5.Mirpursakro & $24.5474^{\circ} \mathrm{N}$ & $67.6260^{\circ} \mathrm{E}$ & 15 \\
\hline 6. Keenjher & $24^{\circ} 45^{\prime} 7.74 \mathrm{~N}$ & $67^{\circ} 53^{\prime} 35.52^{\prime \prime} \mathrm{E}$ & 22 \\
\hline 7. Makli & $24^{\circ} 566^{\prime} 5.99 \mathrm{~N}$ & $68^{\circ} 02^{\prime} 60.00^{\prime \prime} \mathrm{E}$ & 8 \\
\hline 8. Karachi & $24.8607^{\circ} \mathrm{N}$ & $67.0011^{\circ} \mathrm{E}$ & \\
\hline
\end{tabular}

\section{Sampling of carabid beetles}

Adult beetles were trapped by three different methods, hand picking, light trap and pitfall tarp at different localities i-e Thatta, Makli, Keenjher, Sujawal, Ghorabri, Daro and Karachi were surveyed during august 2018July 2019. Each locality was at about $27 \mathrm{~km}$ to $65 \mathrm{~km}$ from another locality (Fig. 1).

In summer season adult ground beetles were collected between 7 am to $7 \mathrm{pm}$, while in winter during the day under the stones and logs. To collect the catch field was visited fortnightly. One light trap and ten pitfall traps were installed per locality and frequency of carabid beetles was observed. After sampling catch were brought to an entomological laboratory department of zoology university of Sindh Jamshoro kept into alcohol, then antennae and legs were stretched and kept in wooden boxes with naphthalene balls in corners and cupcakes powder in sides of boxes. The external characters such as shape and size of antennae were identified under dissecting microscope, following authentic keys and relevant literature [5].

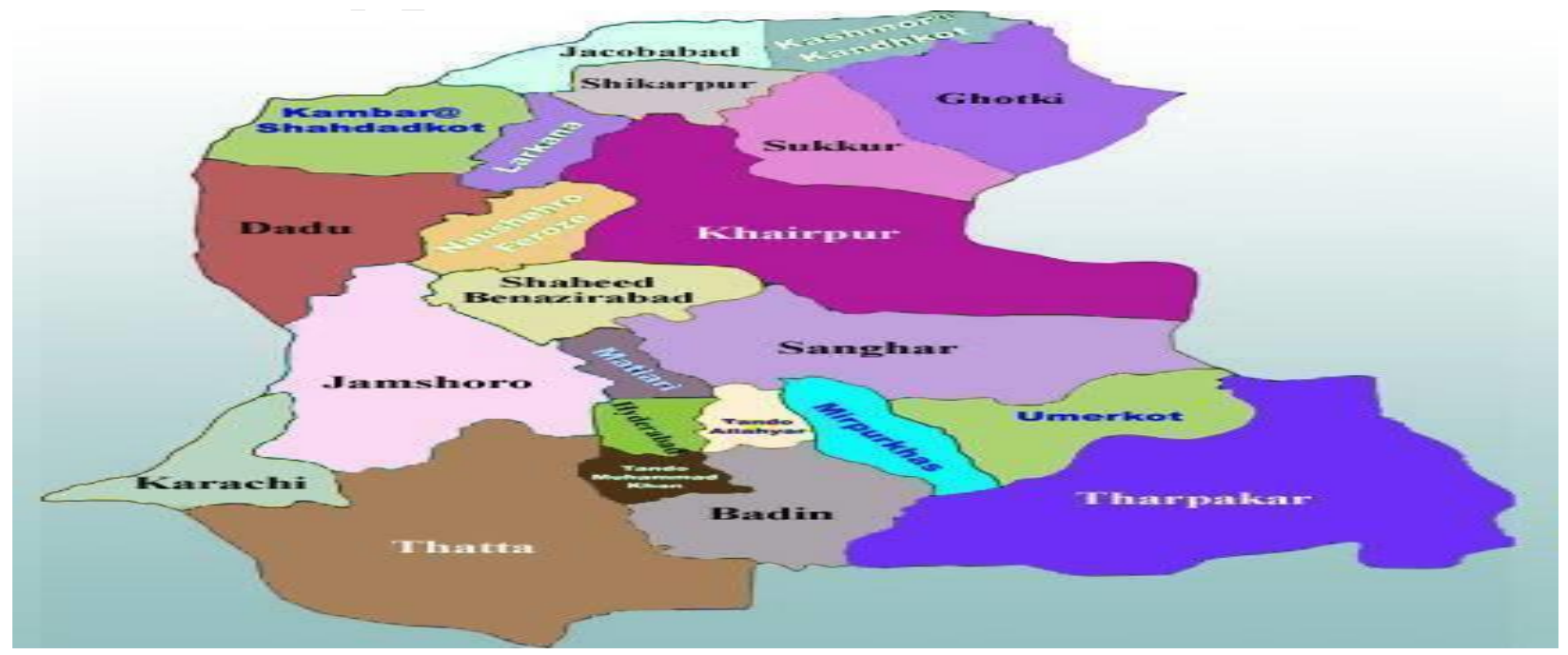

Figure 1. Map showing studied localities 


\section{Data analysis}

To analyze the data, indices of diversity, species evenness and richness of carabid beetles were estimated, to calculate species evenness following equation was used;

\section{$E 1 / D=1 / D$}

$\mathrm{E} 1 / \mathrm{D}=\underline{1 / \mathrm{D}} / \mathrm{S}$

Where; E1/D = Simpson's measure of Evenness

$\mathrm{D}=$ Simpson's diversity index

$\mathrm{S}=\mathrm{No}$ : of species in a sample

To measure simpsons diversity index below equation was followed

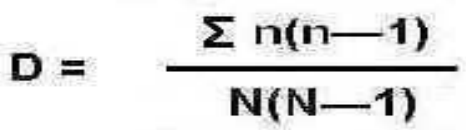

The average population was measured by dividing total number of individuals $(\mathrm{N})$ with species number (S).

\section{Statistical analysis}

The statistically data were analyzed using Pearson's correlation coefficient to measure the strength of linear relationship of biotic factors (host plants) and a-biotic factors (temperature, humidity and rainfall) with the abundance of carabids beetles through software, SPSS 22 version.

\section{Data of climatic factors}

The metrological data of weather variables i.e. Temperature, humidity and rainfall of investigated localities were collected from Regional Agromet Centre Tandojam.

\section{Results}

The outcomes of present study showed that a total 1303 individuals belonging to four subfamilies eight genera and twelve species were listed/ reported from various localities of coastal areas of Sindh Pakistan. The individuals of subfamily Harpalini were higher 508 followed by Carabinae 462 while least number of subfamily Brachinae 130 followed by Lebinae with 157 was recorded (Table 2 \& Fig. 2). Three most abundant species were, Calosoma aurapunctuatum,
Calosoma scyophantum and Anthia sexuamatta (Fig. 3). The seasonal variation has great effect on abundance of carabid beetles, the highest population was recorded in summer season followed by spring whereas least abundance was observed in winter. Monthly population dynamics showed that Carabid beetles were highest in number in months of June, July followed by august and September while least population were recorded in February followed by January and December (Table $3 \&$ Fig. 4). Different habitats / host plants were recognized into four groups of eight localities. (fodder crops, cereals, weeds) and Simpson diversity of Carabid beetles communities was calculated in mentioned localities. (Table 4 \& Fig. 5). The locality Ghorabri with agricultural crops and fodder plants were with great number of individuals (269), followed by Sujawal (268) and Thatta (243), while the locality Karachi with poor vegetation and crops had (70) individuals (Table 5), consequence the highest average population size $(29.7 \%)$ at Sujawal followed by Ghorabri with (27\%) whereas least average population size was recorded in Karachi (11.4\%) as in (Fig. 6). Moreover, the Simpson evenness index was calculated and found highest in Karachi (0.95) locality followed by Mirpur Sakro (0.92), while the lowest evenness index was measured at locality Sujawal (0.74) (Fig. 7). finally, be able to calculate the diversity, the Simpson reciprocal index was computed, and the highest reciprocal index was measured in Thatta (9.46) whilst lowest Simpson reciprocal index was recorded in Karachi locality (5.73) due to poor habitat and climatic conditions (Fig. 5)

Correlation coefficient (Pearson) revealed positive and significant relationship of abundance Carabid beetles with humidity, temperature and rainfall $(\mathrm{r}=.343, \mathrm{p}=.275)$ (Fig. 8), (r=.754, p=.005) (Fig. 9) and $(\mathrm{r}=.301, \mathrm{p}=.342)$ (Fig. 10) respectively. 
Table 2. Showing month wise population of sub-families Carabinae, Harpalinae, Lebinae and Brachinae ground beetles during August 2018-July 2019 in coastal areas of Sindh

\begin{tabular}{|c|c|c|c|c|c|}
\hline Month & Carabinae & Harpalinae & Lebinae & Brachinae & Total \\
\hline August & 57 & 78 & 20 & 18 & 176 \\
\hline September & 30 & 50 & 05 & 12 & 97 \\
\hline October & 27 & 22 & 04 & 07 & 60 \\
\hline November & 30 & 17 & 04 & 05 & 56 \\
\hline December & 11 & 08 & 02 & 01 & 56 \\
\hline January & 09 & 05 & 01 & 01 & 22 \\
\hline February & 08 & 03 & 01 & 02 & 16 \\
\hline March & 28 & 23 & 03 & 05 & 59 \\
\hline April & 23 & 28 & 12 & 10 & 73 \\
\hline May & 29 & 42 & 18 & 22 & 111 \\
\hline June & 120 & 132 & 37 & 43 & 332 \\
\hline July & 90 & 100 & 27 & 31 & 251 \\
\hline Total & 462 & 508 & 157 & 130 & 1303 \\
\hline
\end{tabular}

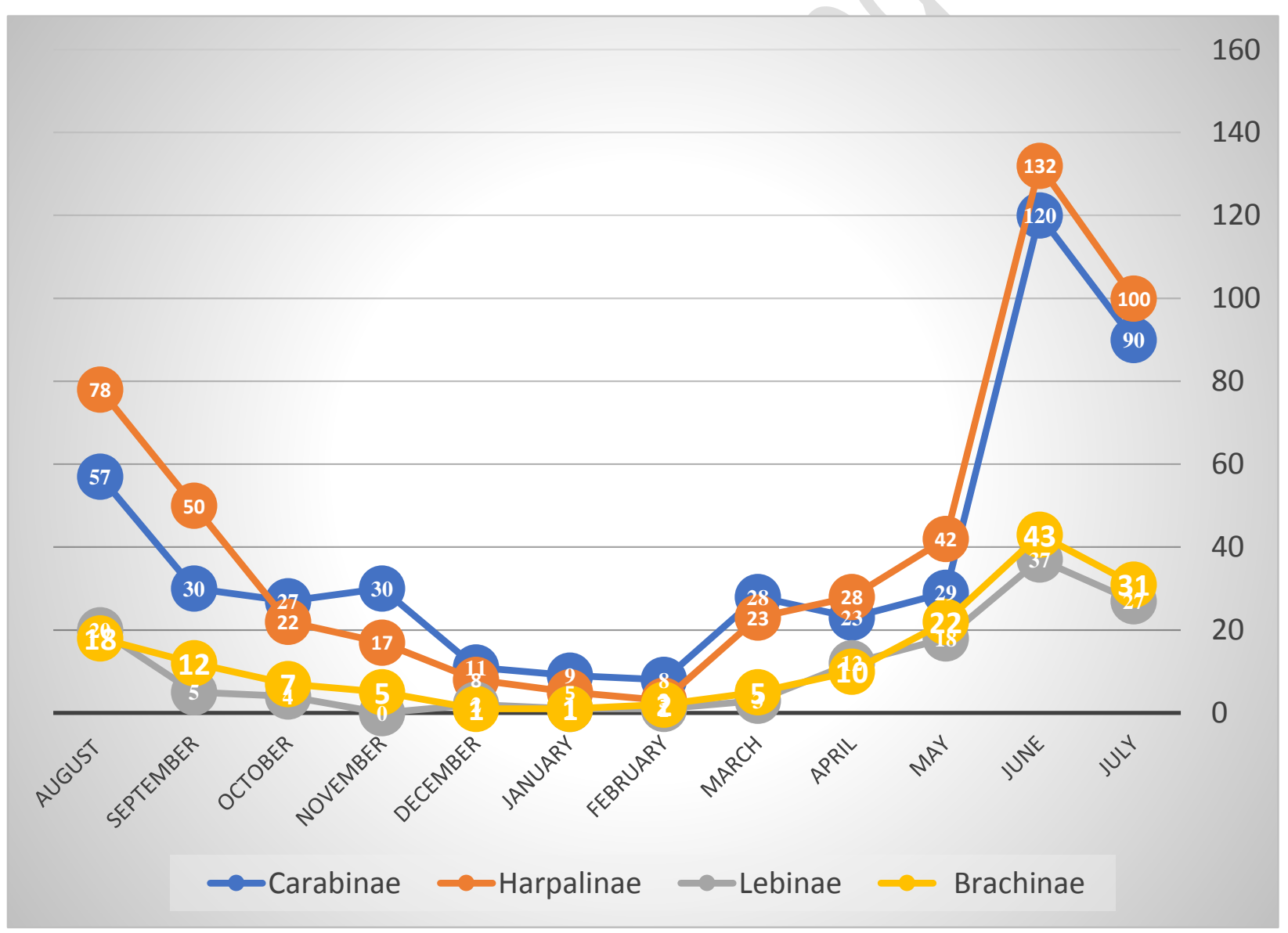

Figure 2. Showing month wise abundance of sub-families Carabinae, Harpalinae, Lebinae and Brachinae ground beetles during August 2018-July 2019 in coastal areas of Sindh 


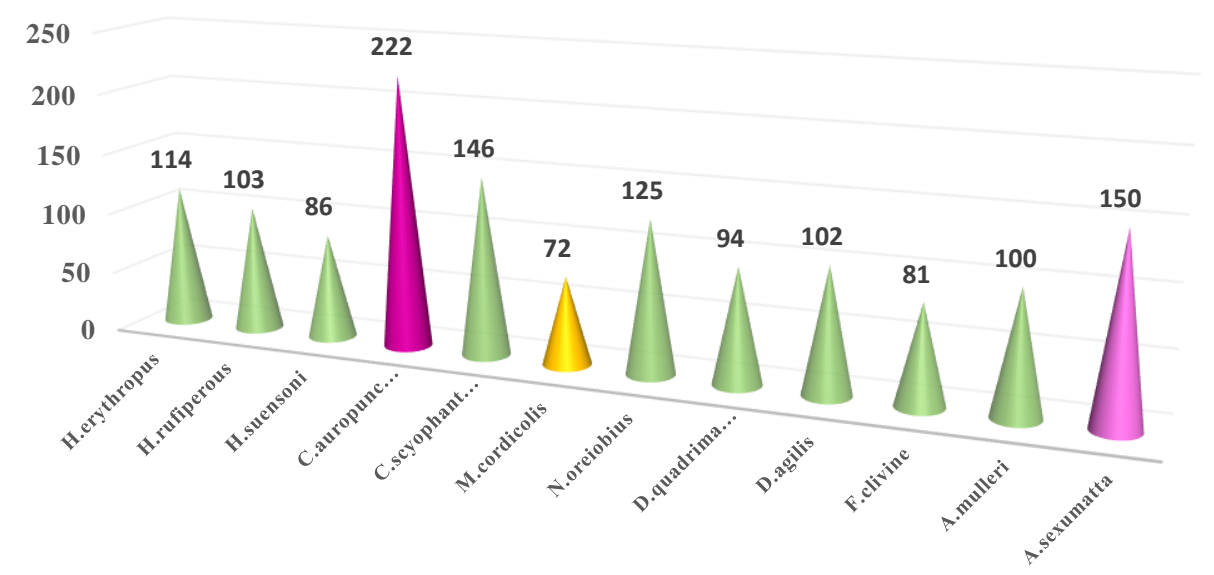

Figure 3. Showing abundance of all collected species of Family Carabidae, ground beetles during August 2018-July 2019 in coastal areas of Sindh

Table 3. Showing habitat wise distribution of carabid beetles in coastal areas of Sindh during August 2018-July 2019

\begin{tabular}{|c|c|c|c|}
\hline S. No. & Name of site & Description of sampling sites & $\begin{array}{c}\text { Specimens of ground } \\
\text { beetles }\end{array}$ \\
\hline 1 & Ghorabri & Fodder crops, bushes, banks of rivers and lakes & 269 \\
\hline 2 & Sujawal & $\begin{array}{c}\text { Cereals, fodder crops, banks of rivers, } \\
\text { woodlands }\end{array}$ & 268 \\
\hline 3 & Thatta & Fodder crops, bushes, banks of rivers and lakes & 243 \\
\hline 4 & Daro & $\begin{array}{c}\text { fodder crops, ornamental flowers banks of } \\
\text { rivers, woodlands }\end{array}$ & 161 \\
\hline 5 & Mirpursakro & Fodder crops, bushes, banks of rivers and lakes & 108 \\
\hline 6 & Keenjher & Fodder crops, bushes, banks of rivers and lakes & 134 \\
\hline 7 & Makli & $\begin{array}{c}\text { Fodder crops, bushes, ornamental flowers, } \\
\text { banks of rivers and lakes }\end{array}$ & 112 \\
\hline 8 & Karachi & Fodder crops, bushes, banks of rivers and lakes & 70 \\
\hline
\end{tabular}

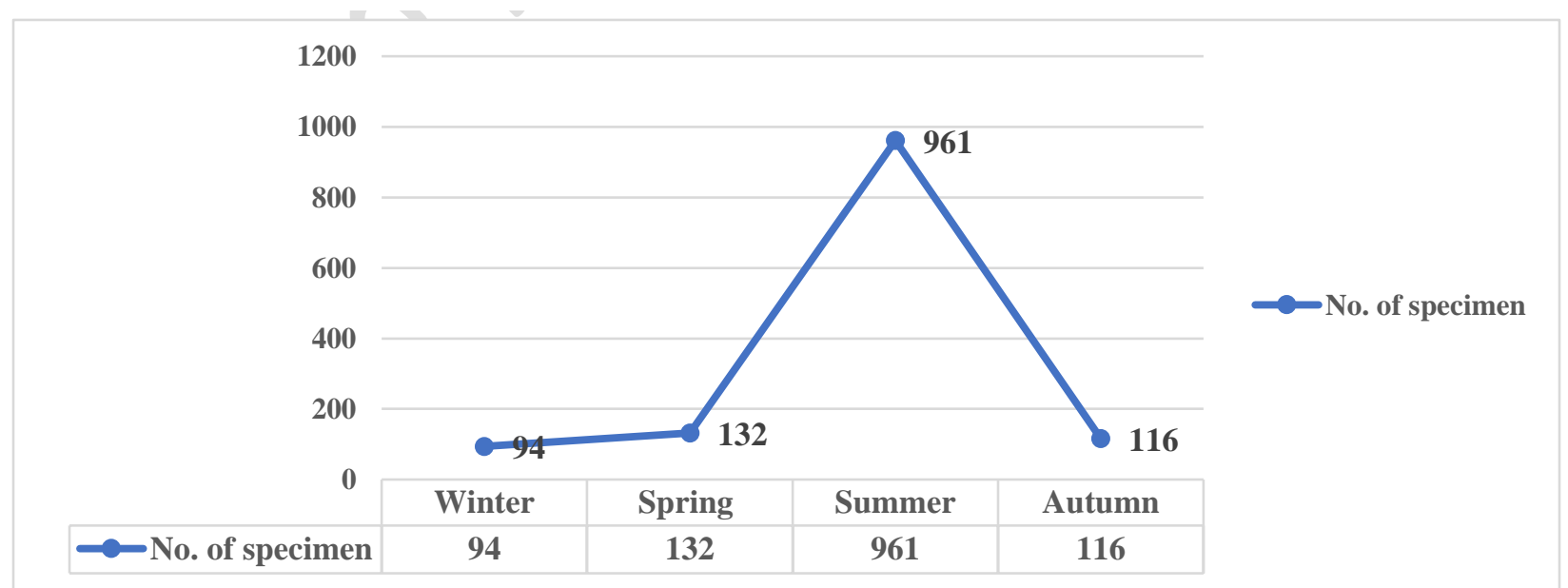

Figure 4. Seasonal variation in abundance of ground beetles during August 2018-July 2019 in coastal areas of Sindh 
Table 4. Metrological observations and abundance of Carabid beetle in coastal areas of Sindh during August 2018-July 2019

\begin{tabular}{|c|c|c|c|c|}
\hline Month & Abundance of carabid beetles & Humidity & Temperature & Rain fall \\
\hline August & 173 & 70 & 30 & 59 \\
\hline September & 97 & 64 & 30 & 34 \\
\hline October & 60 & 46 & 30 & 1 \\
\hline November & 56 & 48 & 25 & 2 \\
\hline December & 56 & 56 & 20 & 2 \\
\hline January & 22 & 57 & 18 & 6 \\
\hline February & 16 & 49 & 20 & 9 \\
\hline March & 59 & 46 & 25 & 11 \\
\hline April & 73 & 50 & 25 & 4 \\
\hline May & 111 & 55 & 33 & 0 \\
\hline June & 332 & 58 & 34 & 5 \\
\hline July & 248 & 68 & 30 & 85 \\
\hline
\end{tabular}

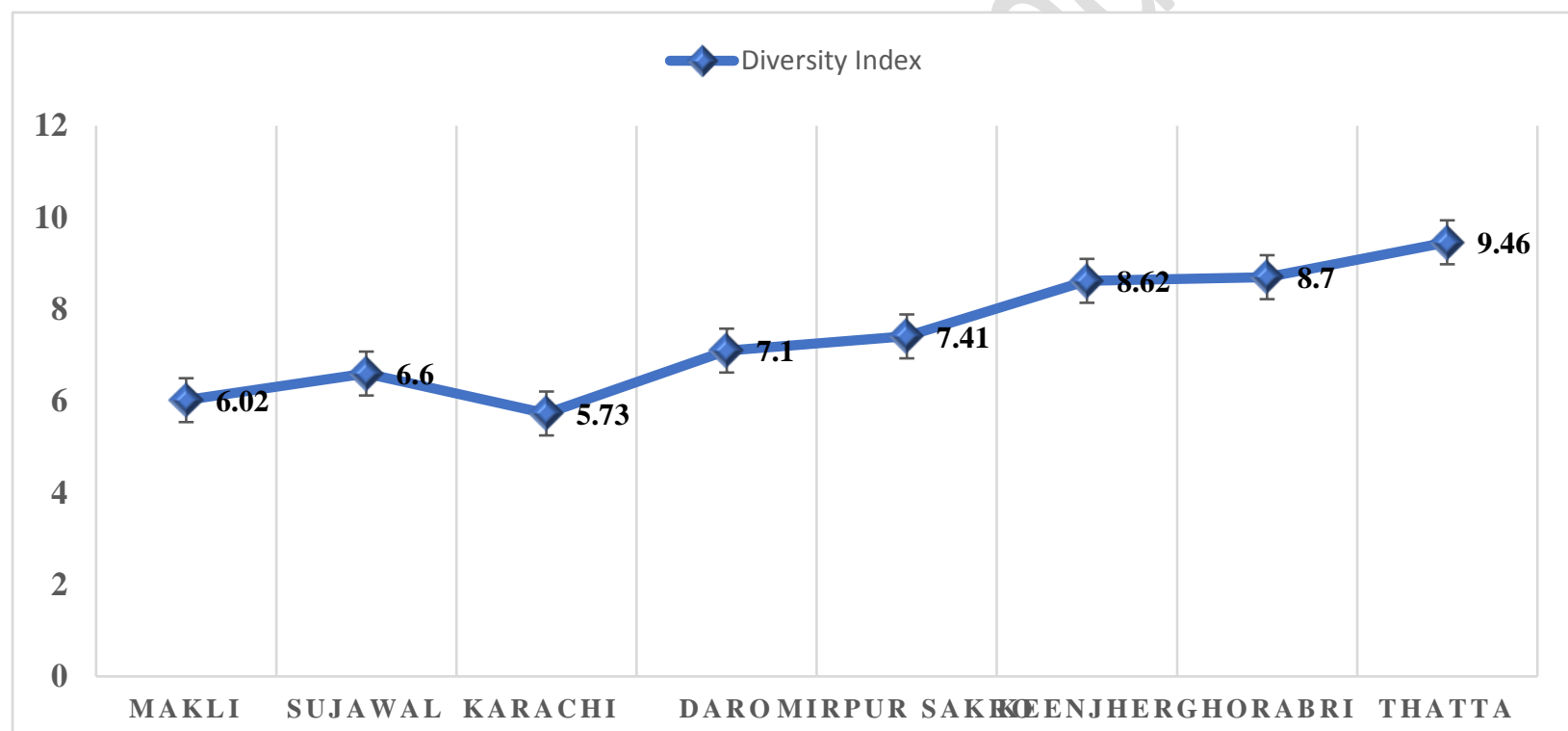

Figure 5. Simpson's diversity Index of carabid beetle communities in eight different localities of Coastal areas of Sindh during August 2018- July 2019

Table 5. Relationship between abundance of beetles and abiotic factors in Coastal areas of Sindh during august 2018-July 2019

\begin{tabular}{|c|c|c|}
\hline Parameters & Pearson correlation "r" & (p value) \\
\hline Temperature $\left({ }^{\circ} \mathrm{C}\right)$ & $\mathbf{. 7 5 4}$ & $\mathbf{0 0 5}$ \\
\hline Humidity $(\%)$ & $\mathbf{. 3 4 3}$ & $\mathbf{. 2 7 5}$ \\
\hline Rainfall $(\mathrm{mm})$ & $\mathbf{. 3 0 1}$ & $\mathbf{. 3 4 2}$ \\
\hline
\end{tabular}




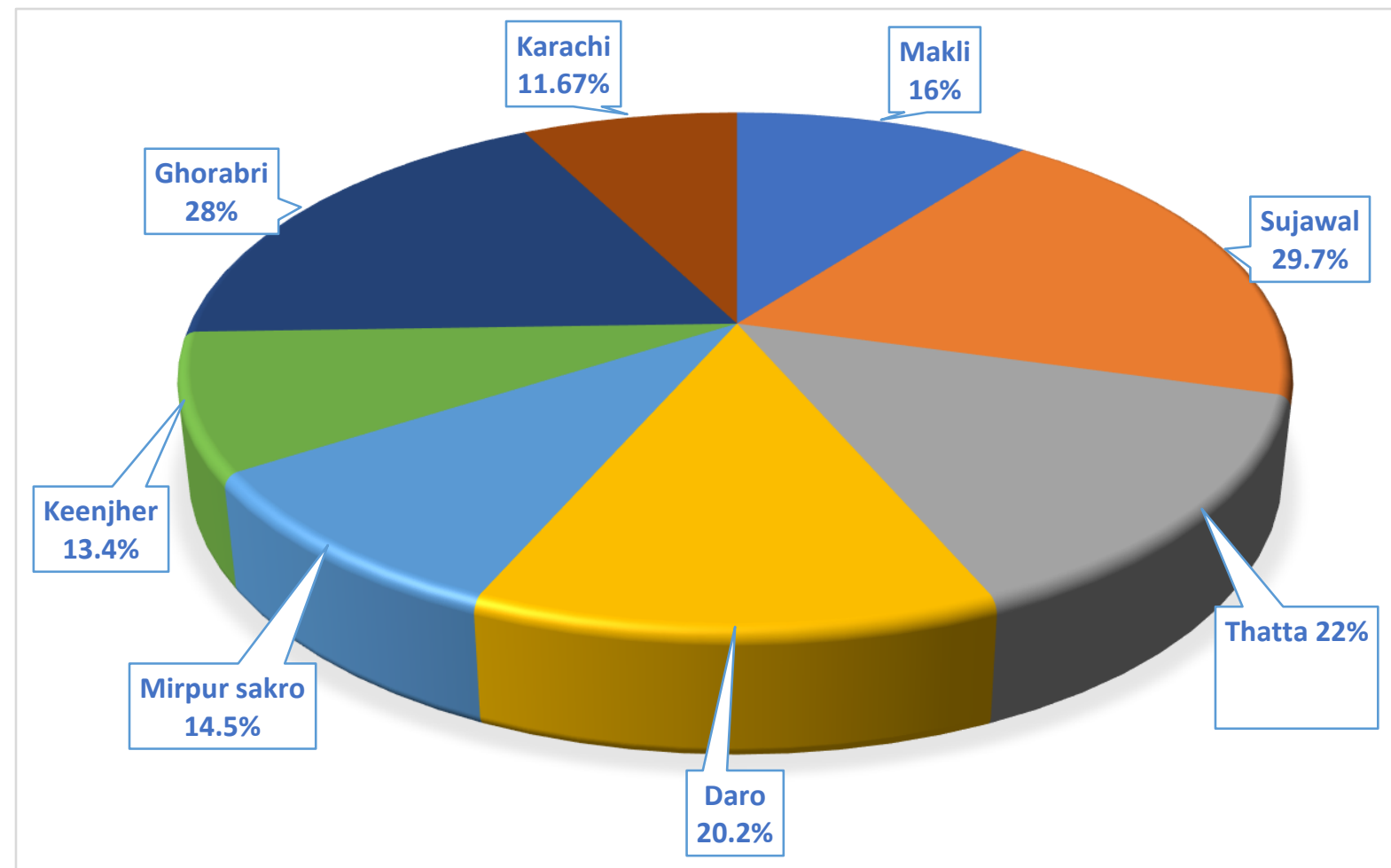

Figure 6. Average population size of carabid beetle communities in eight different localities of Coastal areas of Sindh during August 2018- July 2019

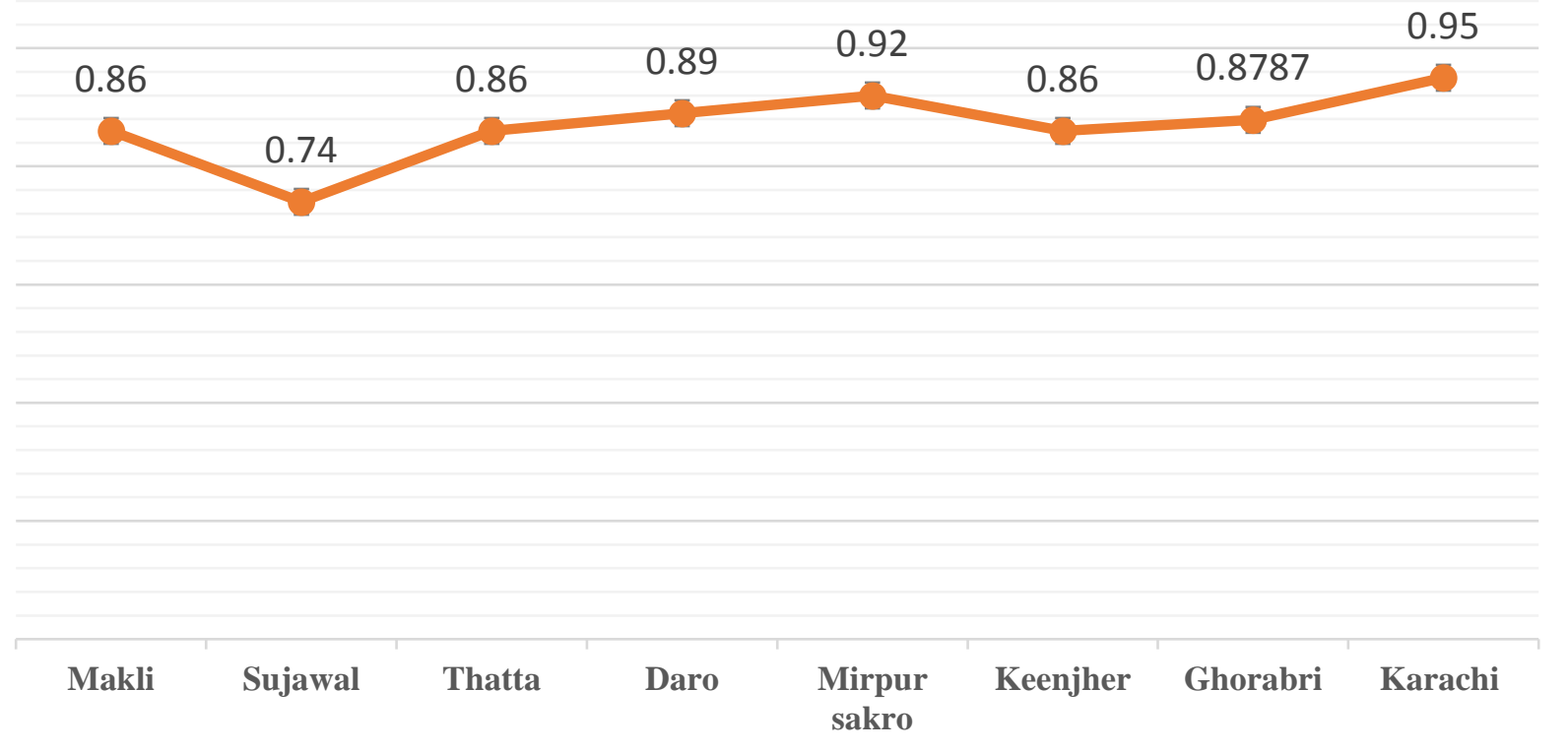

Figure 7. Simpson's diversity Index of carabid beetle communities in eight different localities of Coastal areas of Sindh during August 2018- July 2019 


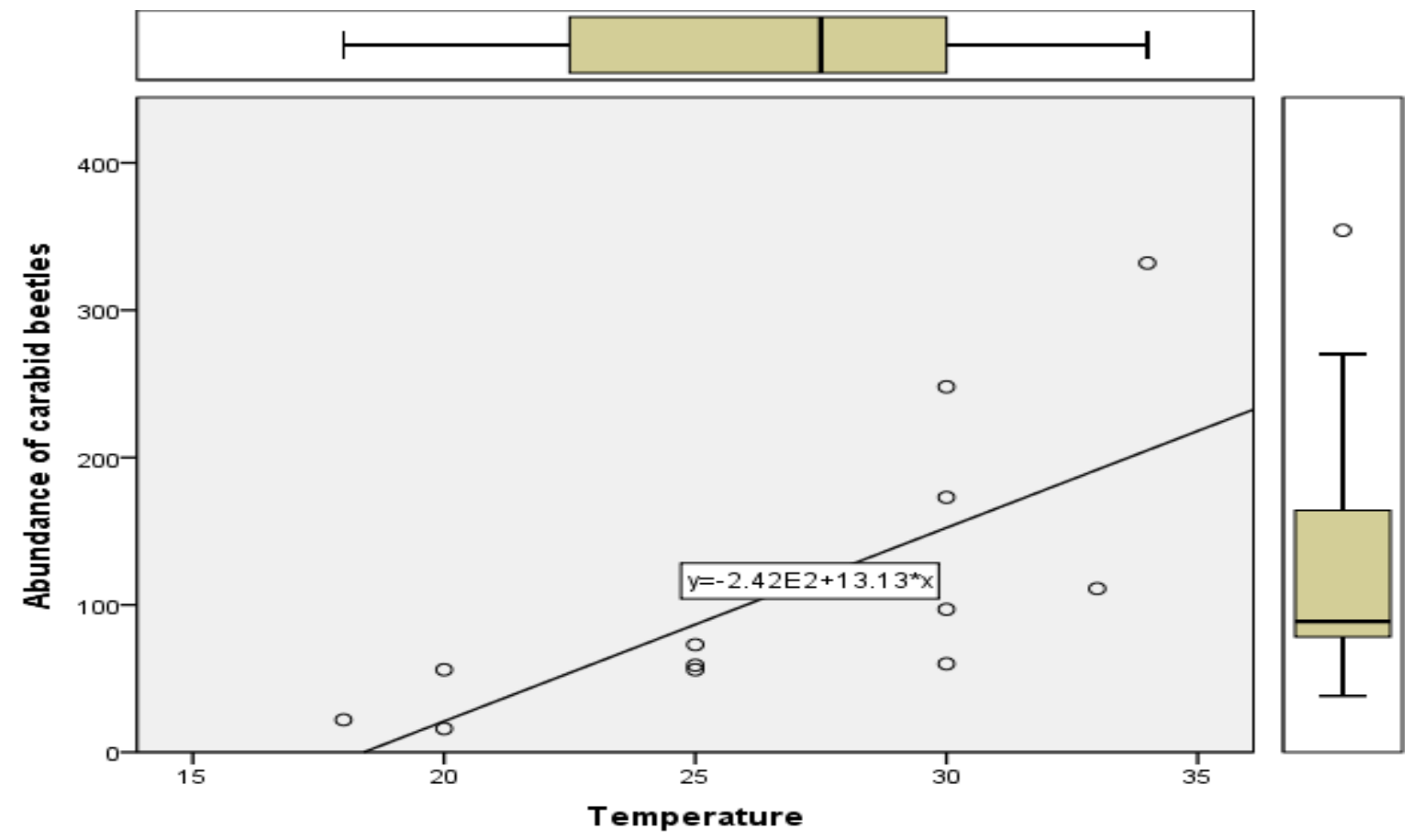

Figure 8. Relationship between average temperature and abundance of ground beetles population in Coastal areas of Sindh during August 2018-July 2019

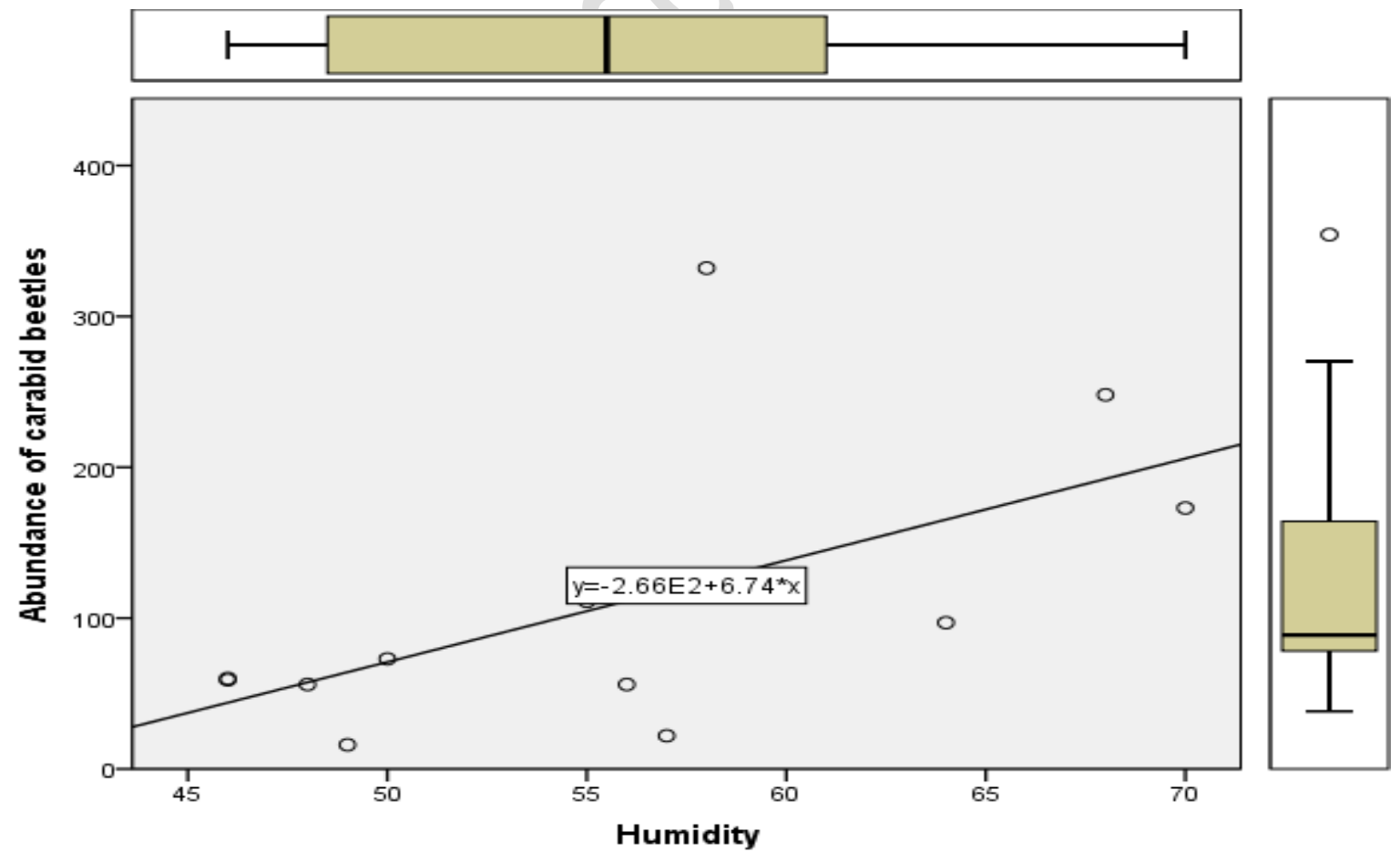

Figure 9. Relationship between relative humidity and abundance of ground beetles population in Coastal areas of Sindh during August 2018-July 2019 


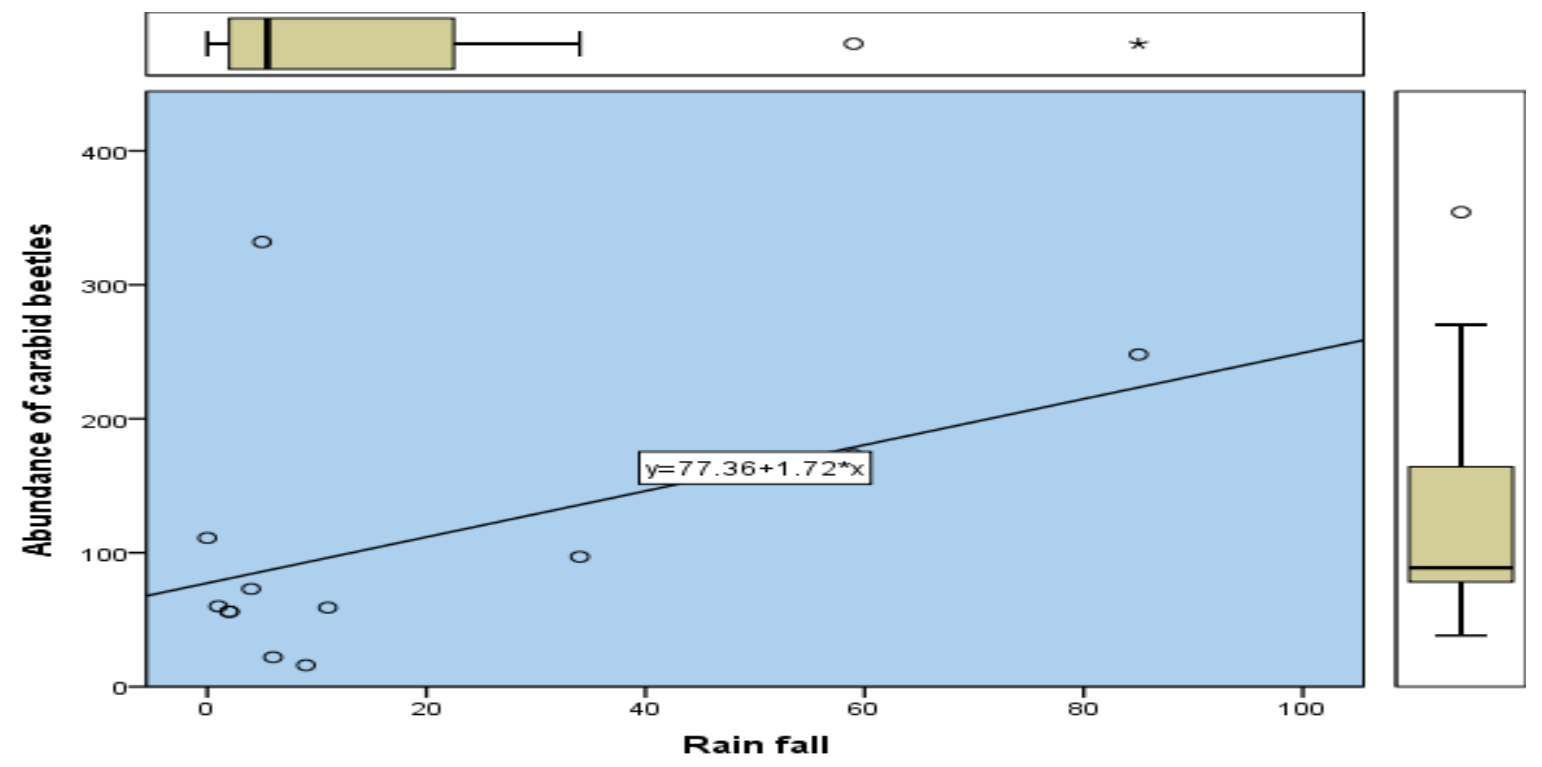

Figure 10. Relationship between rainfall and abundance of ground beetles population in Coastal areas of Sindh during August 2018-July 2019

\section{Discussion}

The seasonal fluctuations revealed that carabid population collected through the year with incredible dynamics and diversity. However, the ground beetles of subfamily Harpalinae were more abundant in eight different localities during August 2018- July 2019 in coastal areas of Sindh. The plentitude of any species in a specific habitat at particular times to be determined by abiotic (temperature, Humidity and rain fall) play a vital role in distribution and abundance of beetles and biotic (host plants, habitats) components of ecosystem remarkable. In southern Sindh (coastal areas of Sindh ) during the summer season the carabid beetle population was recorded high, as in spring there was breeding season and most beetles were in pupal form, then onset of summer most of them have turned into adults, on reach of their favorable climatic conditions such as temperature, humidity and rain fall were present. Among these climatic factors humidity, temperature and rainfall were strongly related and significant with values $(\mathrm{r}=.343, \mathrm{p}=.275), \quad(\mathrm{r}=.754, \mathrm{p}=.005)$ and $(\mathrm{r}=.301, \quad \mathrm{p}=.342)$ respectively. [19] determined the interrelation between ground beetles and meteorological parameters vary with geomorphological distributions. [20] reported population of ground beetles increases with an increase in precipitation and is significant during wetter months, rainfall is related to abundance in terms of leaf fall, litter moisture and decomposition of litter. [21] observed grazing has negative effect on carabidofauna, as they have positive effect of non-grazed biomass areas in abundance. This work has been done the first time on seasonal variation of Carabid beetles from Sindh, Pakistan, so our results are in accordance with [22] that climatic factors (humidity, average, temperature) have strong and significant correlation with carabid population size. This interaction reveals that long term changes can affect diversity and biomass of carabidofauna in environment. Representatives of subfamily Harpalinae and Carabinae were in higher numbers than Lebinae and Brachinae, previous are more 
resistance to ecological conditions than later but, all are recorded in great number in the warmest months $\left(45^{\circ} \mathrm{C}\right)$ June, July and August while in coldest winter all four were counted in least number. Furthermore, in eight localities species composition and diversity were unalike i-e Sujawal locality with fodder crops, agricultural and much wet habitat has great population size and diversity on the contrary Karachi locality was in poor habitat with low agricultural and fodder crops so both was least abundance and average population, which leads to low richness and diversity index, this is because of fact that less availability of fodder and agricultural crops and suitable habitat with reference to other localities.

\section{Conclusion}

It is concluded that temperature, humidity and rain fall (abiotic) are key factors affecting the abundance of carabid species, besides this heterogeneity in ecosystem play a function. Furthermore, the locality with the high average population size and high richness results high diversity index whilst, the habitat/locality with low abundance and average population size give rise to low diversity index.

\section{Authors' contributions}

Conceived and designed the experiments: $\mathrm{N}$ Memon, Performed the experiments: R Sahito, Analyzed the data: R Sahito, Contributed materials/ analysis/ tools: A Amur \& R Sahito, Wrote the paper: R Sahito.

\section{References}

1. Lorenz W (2005). Systematic list of extant ground beetles of the world (Insecta, Coleoptera "Geadephaga: Trachypachidae and Carabidae incl. Paussinae, Cicinidelinae, Rhysodinae). Tutzing, Germany, pp 530.

2. Spellerberg IF (1993). Monitoring Ecological Change. Cambridge University Press, Cambridge, UK. Spence JR and Niemela JK 1994. Sampling ground beetle assemblages with pitfall traps the madness and the method. The Canadian Entomol 126: 881-894.

3. Schowalter TD (1995). Canopy arthropod communities in relation to forest age and alternative harvest practices in western Oregon. For Ecol Manage 78: 115-125.

4. Akutse K, Khen CV \& Toda MJ (2007). Assessment of higher insect taxa as bioindicators for different loggingdisturbance regimes in lowland tropical rain forest in Sabah, Malaysia. Ecol Res 22: $542-550$.

5. Lindroth $\mathrm{CH}$ (1966). The ground-beetles (Carabidae, excl. Cicindelinae) of Canada and Alaska. Part 4. Opuscula Entomologica Supplementum 29: 409648.

6. Larochelle A \& Lariviere MC (2003). A natural history of the ground-beetles (Coleoptera: Carabidae) of America north of Mexico. Pensoft Series Faunistica, SoPa, Bulgaria.

7. Janzen DH (1973). Sweep samples of tropical foliage insects: Effects of seasons, vegetation types, elevation, time of day, and insularity. Ecol 54: 687708.

8. Rainio J \& Niemelä J (2003). Ground beetles (Coleoptera: Carabidae) as bioindicators. Biodiver and Conserv 12: 487-506.

9. Wolda H (1978). Fluctuations in Abundances of Tropical Insects. Am Nat 112: 1017-1045.

10. Wolda H (1983). Seasonality of Homoptera on Barro Colorado Island. In: Leigh jr. EG, Rand AS, Windsor DM. (Eds.). The Ecology of a Tropical Forest. Seasonal Rhythms and Long-term Changes Smithsonian Institution Press 319-330.

11. Wolda H (1988). Insect Seasonality: Why? Annu Rev Ecol Syst 19: 1-18. 
12. Dufrene M \& Legendre P (1997). Species assemblages and indicator species: the need for a flexible asymmetrical approach. Ecol Monographs 67: 345-366.

13. Lovei GL \& Sunderland KD (1996). Ecology and behavior of ground beetles (Coleoptera: Carabidae). Ann Rev Entomol 41: 231-256.

14. Erwin TL \& Scott JC (1980). Seasonal and Size Patterns, Trophic Structure, and Richness of Coleoptera in the Tropical Arboreal Ecosystem: The Fauna of the Tree Luehea seemannii Triana and Planch in the Canal Zone of Panama. The Coleopterists Bull 34: 305-322.

15. Tanaka LK \& Tanaka SK (1982). Rainfall and Seasonal Changes in Arthropod Abundances on a Tropical Oceanic Island. Biotropica 14: 114-123.

16. Pearson DL \& Derrs JA (1986). Seasonal Patterns of Lowland Forest Floor Arthropod Abundance in Southeastern Peru. Biotropica 18: 244-256.

17. Hammond P (1990). Insect abundances and diversity in the Dumoga-Bone National Park, N Sulawesi, with special reference to the beetle fauna of lowland rain forest in the Toraut region. In: Knight WJ, Holloway JD. (Eds.) Insects and the Rain Forests of South East Asia (Wallacea), 197-254.
Entomological Society of London, London.

18. Nummelin M (1996). The Community structure of arthropods in virgin and managed sites in the Kibale Forest, Western Uganda. Trop Ecol 37: 203213.

19. Rainio J (2013). Seasonal Variation of Carabid Beetle (Coleoptera: Carabidae) Abundance and Diversity in Ranomafana National Park, Madagascar. $J$ of Entomol and Zool Stu 1(5): 92-98.

20. Dawn C \& Frith C (1990). Seasonal variation in a diverse beetle assemblage along two elevational gradients in the Australian Wet Tropics C. W. Wardhaugh1,3, MJ Stone 2 \& NE Stork. Biotropica 22(2): 181-190.

21. Byers RA, Barker GM, Davidson RL, Hoebeke ER \& Sanderson MA (2000) Richness and abundance of Carabidae and Staphylinidae (Coleoptera), in Northeastern dairy pastures under intensive grazing. Great Lakes Entomol 33: 81-105.

22. Crystal M, Ernst, Loboda S \& Christopher MB (2015). Capturing northern biodiversity: diversity of arctic, subarctic and north boreal beetles and spiders are affected by trap type and habitat. Insect Conservation and Diversity. 